\title{
Purposeful Travel to Nepal: An Ethnographic Study of the Eudemonic and Hedonistic Experiences of Volunteers
}

\author{
Susanna Curtin ${ }^{1}$ \\ ${ }^{1}$ School of Tourism, Bournemouth University, Dorset House, Talbot Campus, Fern Barrow, Poole, Dorset, \\ UK. BH12 5BB
}

\begin{abstract}
Purposeful travel is apparent in relatively new modes of tourism and particularly in volunteer holidays where tourists are searching for meaningful experiences which provide a sense of physical, emotional or spiritual fulfilment. The positive outcomes of volunteer holidays on destinations is heavily debated from questioning the morals and merits of a growing profit-making sector to whether destinations have little or no long term benefit from such travel. Whilst the author acknowledges the wealth of literature in this regard, she concentrates on the notion that volunteering is not just about helping other people or worthy causes but also about personal self-development and social egoism. She concludes that these two features have eudemonic outcomes and that these are worthy of investigation. Based on an ethnographic study, this paper analyses the experiences of participants on an elephant conservation expedition to Bardia National Park, Nepal. In its evaluation it conveys the close relationship between altruism and egoism as well as the eudemonic outcomes that purposeful travel can sometimes provide.
\end{abstract}

\section{Volunteering as Purposeful Travel}

Travelling with a purpose is an inherent aspect of volunteer tourism where tourists are searching for meaningful experiences which provide a sense of physical, emotional or spiritual fulfilment [1-2]. Volunteer tourists can be described as "individuals from Western countries paying to come to the Third World to assist with development or conservation work, as they desire to achieve something more meaningful than a pleasure filled, self-indulgent holiday' [3], or similarly, as "purpose-driven travellers who seek meaningful journeys" [4]. In principle volunteer tourism is a means of assisting communities, species and habitats in need of help. It has been applauded for its dual objectives of building international understanding and relations, fostering cross-cultural experiences, promoting tolerance, global awareness and civic engagement as well as supporting tourists' own personal development [5]. It satisfies a longing for adventure and travel whilst providing valuable services to the communities visited [6]; thus volunteer tourism is a 'win-win' type of travel where destinations benefit but also the psychological well-being of the tourists who take part. These journeys transform and enhance aspects of the self [7]. Specifically volunteer tourism provides authentic and meaningful life experiences which enriches or alters attitudes, behaviour, values, knowledge and skills [8]. To the critics of volunteer travel this confirms that volunteering is more about egoism than altruism: tourists' seemingly selfless contributions to local communities and environments may in fact be self-serving attempts to boost their own image [9-11]. 
Moreover, the positive and negative outcomes of volunteer holidays on destinations are heavily debated from questioning the morals and merits of a growing profit-making sector to whether destinations have little or no long term benefit from such travel [12]. It has also received much criticism for its tendency to reinforce rationalisations of colonialism and poverty due to the focus on travel to developing countries [13-14] especially given that short periods of time at a destination do little to alleviate long term problems [15]. Whilst the author of this paper acknowledges the wealth of literature in this regard, she concentrates on the notion that volunteering is not just about helping other people or worthy causes but also about personal self-development and social egoism [16].

The aim of this research is to explore the eudemonic outcomes of tourists on a volunteer conservation expedition. Eudemonia is based on a theory from positive psychology and is a new field of tourism research [17]. It follows that a eudemonic study of expedition volunteers provides a fresh and more honest focus to conservation volunteering as it assumes that true happiness is found in the expression of virtue; in doing what is worth doing, which is a fundamental source of well-being and overall life satisfaction. This puts a new perspective on volunteer travel beyond the already researched and polarised paradigms of hedonism and altruism.

\subsection{Volunteers' Intrinsic Motivations: Eudemonia, Happiness and Subjective Wellbeing}

The research on volunteer tourist motivations has been relatively extensive and indeed points towards a complex milieu of altruistic and self-orientated motivations. Motivations are mostly categorised under four major themes; namely, cultural immersion [18], seeking camaraderie [19], pursuing educational opportunities and giving back to society [20]. In a previous study of why people volunteer, similar functional motives were identified; 'functional' meaning that the behaviour serves particular psychological needs [21]. These were: 1) a way of protecting the ego from the difficulties of life by reducing guilt and overcoming negative self-concept or negative feelings about life (i.e. these are known as protective motives). 2) A way to express one's altruistic and humanitarian values (i.e. value motives). 3) A way to improve career prospects (i.e. career motives). 4) A way to develop and strengthen social ties (i.e. social motives). 5) A way to gain knowledge, skills, and abilities (i.e. understanding and knowledge motives), and 6) a way to help the ego grow and develop (enhancement motives). These concepts are useful markers and will be discussed in further publications at a later date. Volunteer motivations are thus rooted in a personal quest for 'meaning',' 'happiness' and 'wellbeing' which are far-reaching constructs in their right.

The theory of 'authentic happiness' is fundamental to understanding the feelings of well-being [22]. It is suggested that happiness can be measured against three criteria: positive emotion (feeling good), engagement (absorption and flow) and meaning (belonging to and serving something that you believe is bigger than the self. Hedonic philosophers such as Epicurus, held the belief that human beings are motivated by the optimization of individual pleasure, i.e. maximising pleasure and minimising pain [23]. In contrast the philosophical roots of the eudemonic tradition can be traced back to Aristotle and Plato [24]. For Aristotle human happiness and wellbeing is embedded in far more than the search for individual pleasure and the avoidance of pain, instead eudemonic wellbeing derives from a human need to find meaning and fulfill one's true potential which is to be found in collective and social relationships. The promise of a good life is in the quest for meaningful individual and social goals [25]. Eudemonia is thus not conceived as a mental state, a positive feeling, or a cognitive appraisal of satisfaction, but rather as a virtuous way of living. Although the quantitative tradition is deeply rooted in positive psychology, there are calls for greater use of qualitative approaches to understanding happiness within the context of tourist experiences [26]. This research therefore adopted an ethnographic method of participant observation in order to immerse the researcher in the setting and experience the volunteering phenomenon first hand.

\section{Study Context and Methods}

Overseas conservation volunteering is offered by a number of international conservation organisations who can combine conservation activities and research projects with the opportunity for tourists to travel to 
exotic or remote locations in order to volunteer their services. The expedition charity with whom the authors travelled was founded in 1969 by a well-known British explorer as a non-profit making organisation which organises a worldwide programme of scientific expeditions, conservation, education and community aid projects. One of these projects in April 2012 was to study a herd of wild elephants in Bardia National Park, Nepal whilst at the same time supporting elephant (and tiger) conservation by winning the hearts and minds of the local population who reside in the buffer zones of the national park. Part of this aid included running dentistry and medical clinics and raising money to support victims of elephant raids. Participants applied to join the expedition and were then recruited according to the skill requirements of the project and how well the organisers felt the individual would contribute to the team effort. All members of the expedition were given a specific role according to their expertise. Everyone's reasons for coming on the trip were made clear and thus it was easy for the author to announce the aims of the research and request permission to interview fellow volunteers. See Table 1 for participants' profiles.

Fieldwork was conducted during April/May 2012 when 12 in-depth qualitative interviews were undertaken towards the end or part-way through the trip. A semi-structured, conversational style of interview was adopted [27]. The research questions were organised under three a priori themes. These were: motivations for joining the expedition; personal development and reflections on the high and low feelings experienced during the expedition. Following data collection, a much more detailed review of literature was undertaken in an iterative fashion.

Table 1: Participant Profiles

\begin{tabular}{|l|l|l|c|l|}
\hline $\begin{array}{l}\text { (Pseudo) } \\
\text { Name }\end{array}$ & Gender & Age & Previous expeditions & Role \\
\hline Richard & Male & $\begin{array}{l}\text { Late } \\
50 \mathrm{~s}\end{array}$ & Yes & Dentist \\
\hline Gavin & Male & $\begin{array}{l}\text { Late } \\
30 \mathrm{~s}\end{array}$ & Yes & Artist \\
\hline Barry & Male & $60 \mathrm{~s}$ & No & Doctor \\
\hline James & Male & 18 & No & Ornithologist \\
\hline Tim & Male & $30 \mathrm{~s}$ & Yes & Expedition photographer \\
\hline Rosa & Female & $40 \mathrm{~s}$ & Yes & Scientist \\
\hline Roger & Male & $50 \mathrm{~s}$ & Yes & Expedition reporter \\
\hline Anita & Female & $20 \mathrm{~s}$ & No & Dentist \\
\hline Diana & Female & $\begin{array}{l}\text { Late } \\
50 \mathrm{~s}\end{array}$ & Yes & Assisting the dentistry \\
\hline Ruth & Female & $40 \mathrm{~s}$ & No & Scientist \\
\hline Marcus & Male & $70 \mathrm{~s}$ & Yes & Radio technician \\
\hline Anne & Female & $40 \mathrm{~s}$ & No & Assisting the dentistry \\
\hline Susanna & Female & $40 \mathrm{~s}$ & No & $\begin{array}{l}\text { Ecotourism specialist } / \\
\text { Lepidopterist and researcher }\end{array}$ \\
\hline
\end{tabular}

Once all the interviews were conducted, multiple readings of the transcripts ensued. This allowed the final coding of themes and the eventual condensing and expansion of the initial thematic framework. The line-by-line thematic analysis of the 12 interviews resulted into 61 open codes that were then organised into 12 axial codes or categories. These are represented in Table 2. The following results are organised under the major headings depicted in the 'major categories'. Only some of the key findings are represented in this conference paper. A full academic discussion will be published at a later date. 
Table 2: Thematic Framework

\begin{tabular}{|l|l|}
\hline Major categories & Categories (Axial codes) \\
\hline \multirow{3}{*}{ Finding happiness through travel } & $\begin{array}{l}\text { Why travel instills happiness, } \\
\text { Purposeful travel } \\
\text { Satisfying an adventurous spirit } \\
\text { The importance of place }\end{array}$ \\
\hline \multirow{3}{*}{ Self-orientation } & $\begin{array}{l}\text { Physical fitness } \\
\text { Developing self } \\
\text { Feeling useful }\end{array}$ \\
\hline Orientation towards others & $\begin{array}{l}\text { Getting on with others } \\
\text { Doing good and feeling a sense of pride }\end{array}$ \\
\hline $\begin{array}{l}\text { Happiness, contentment and } \\
\text { volunteering }\end{array}$ & $\begin{array}{l}\text { Key moments of happiness } \\
\text { Experiences of conservation and local people } \\
\text { Time to reflect }\end{array}$ \\
\hline
\end{tabular}

\section{Findings and Discussion}

\subsection{Happiness Through (purposeful) Travel}

Travel is a fundamental desire and aspiration for this eclectic group of individuals. The reasons for this are complex and multi-faceted; sometimes purely frivolous and sometimes deeply philosophical. Responses range from how travel is "the perfect antidote to my life" (Gavin), "a good distraction from normal life" (Jack), an "escape from the drudgery of work" (Roger) and "something to look forward to" (Tim), to "seeing what is going on in the world" (Barry). The consensus is that by "travelling outside of your comfort zone you get a much more realistic view of the world; facing realism rather than escaping from it (Gavin).

Travel provides both a physical and mental space to "just be yourself - it's very freeing" (Jack) or it "allows you to fulfil your aspirations" (Diana) and "reclaim your soul" (Gavin). The awareness of self is very prominent in explanations with some participants apologising for the seemingly selfish desire to be liberated from the everyday. For Richard: "existing in one place all the time, from a selfish point of view is just, however beautiful it is where we live, would be just imprisonment for me. I feel trapped, imprisoned, get frustrated, and get bad tempered. So these sorts of trips actually solve that problem, you know, they allow you to wander a bit". Similarly for Ruth: "there is a selfish aspect in as much as travelling allows me to be me. I find a different part of myself and it is a selfish thing". Travel also provides a new line of sight. For Rosa and Anita the eudemonic outcomes of travel are found in what you bring back to normal life: "I think going to other places makes you look on your own world in a completely different way” (Rosa).

This search for meaning and personal change is an integral aspect of participants' perceptions of purposeful travel. Volunteering is an opportunity to push the inner self, achieve a personal outcome and give something back in the process. These quotations reveal how participants question, or are aware of, the dual nature of purposeful travel (i.e. giving and getting back) and they make little attempt to conceal how their motives are often primarily self-orientated:

"I need to go on holiday to do something, rather than just sit around" (Roger). "You enjoy your surroundings more if you have a reason to be looking or focusing specifically" (Ruth). "You are not just travelling and exploring a new country, you are exploring yourself as well, as you discover new things; you discover new things about yourself" (Gavin). "I don't think the two; the charitable element would work if you didn't want to travel. So selfishly yes, my own needs for travel are there first and then if there 
is a charitable element I can service that as well" (Richard). Charitable deeds can enhance feelings of self-worth and self respect as Diana explains: "Every time I do any kind of volunteer work. It always makes me feel more self-gratification and self-respect for being able to give without worrying about what I'm getting out it or anything like that learning just how satisfying it is to give without having any idea of getting anything back out of it".

Purposeful travel is clearly not perceived as purely altruistic but a mixture of personal achievement and development alongside a purposeful goal which is "to go out there and to try and make a small difference somewhere (to try and help people), but also to grow yourself as a person..... and accomplish something" (Tim). There is an "opportunity to give back a little bit rather than just throw money at a hotel and lay on a beach someplace" (Diana). Overall, "we didn't take anything from them, we gave rather than took" (Richard). Some participants really questioned the blurring and confusion between volunteering and vacationing: "the amount of money that we are paying to come on this expedition blurs the boundaries between holiday, and volunteering, and work, but also the fact that it was a selection process of what we could offer the expedition in terms of our skills. This orientates it more towards volunteering. Yet whilst we are here there is a lot of free time, vacation, and that orientates it more towards vacation" (Diana).

\subsection{Self-orientation}

Nevertheless, the expedition allowed many of the participants to learn more about themselves which they believed enabled them to be better people on their return, as Richard explains: "over time travel like this reduces the "hideous arrogance and self importance. It makes me very tolerant and more compliant with everyone's everyday life".

The expedition was therefore not only a geographical journey but also a personal one in which participants often questioned their abilities to work as a team, to get on with people from all walks of life, to be less sanctimonious and to cope with physical discomforts. Opportunities came and went for them to reflect on their strengths and weaknesses, skills and personality traits that could be enhanced or moderated for the benefit of others: "it really does make you realise a lot of things about yourself, probably good and bad" (Anita). As Ruth concluded, these moments of truth and reflection are seen as a way to "understand myself better... also of what I like and what I need". The implications of this understanding spill over into thoughts of everyday life: "I think this time I've learned some strengths that I wasn't really aware I had in a group, which isn't just to do with this trip" (Rosa). Similarly: "my previous expedition was fundamentally life-changing. I learnt that I could rely on myself a lot more in some situations, and question my own values and judgments in others" (Tim). Often participants suggested that they liked themselves more for volunteering their services. Adaptability was an aspect of self that was universally applauded particularly in the acceptance of local norms and having the empathy to see life through the eyes of others; all this culminated in a "good boost to your confidence and self-esteem" (Tim). People's perceptions of themselves were not always positive, however, there was a constant evaluation of personal limitations as the following quotations illustrate: "sometimes you think you can do something and it turns out that you can't" (Tim). "It's learning about myself in terms of what my limits are of what I can and can't do" (Rosa), and "running your own clinic, working out the boundaries you've got..... it's really working out what you can and can't do, so it's kind of knowing your own limits and working around them" (Anita).

Whilst the absence of significant others provided liberation from everyday roles and the mental space to contemplate new ways of being, getting on with people was a fundamental and universal concern for expedition participants. "Will I fit in?" (Gavin) was a common apprehension prior to the trip. Some feared "a clash of personalities or a fear that there are some people I may not get along with" (Robert). Overcoming such fears and getting on with everyone was also often seen as a achievement: "I learned to 
get on with people I wouldn't have dreamed I would ever get on with. You know, I'm very proud of myself for that. I've crossed a lot of bridges and I think I came away a better person for it" (Gavin). Similarly James noted how "the camaraderie really has been good even though there was a potential for me to be an outsider being significantly younger".

\subsection{Orientated Towards Others}

Feelings of 'being of use', 'contributing' and 'doing good' were therefore critical to the eudemonic outcomes of being on the trip. Although there was a selection process to join the expedition, some of the participants worried about how much they could contribute: "everyone is going to be a doctor, dentist, engineer, and I'm none of the above" (Roger). "Am I qualified enough? What will my duties be? Am I going to be relevant to what is needed? Also working within a team, because I'm not used to working within a team"(Gavin). "I'm not a dentist; I can't do anything like that. I'm not a teacher; I can't contribute to a school. So sometimes I do feel, well yes, doing, you see projects advertised via Earth Watch or whatever, and they are always looking for useful people. You think, yeah but I'm not useful" (Rosa).

It became clear on the expedition that these feelings ran deep: "obviously if you are a dentist or a doctor that's great, but if you are not you are looking on, it makes you feel like a spare hand and everybody I've spoken to on the trip who wasn't involved directly with the dentistry and the hospital work, whatever, felt like they were useless at that time" (Gavin). Others felt similar: "I did feel decidedly under qualified" (Jenny), "I didn't really do anything particularly skillful. My skills are in a different direction, there was not much there that I could exercise my skills at" (Robert). "It's important to me that it has a scientific aspect and it's important to me that I have a proper place within that expedition. I don't want to come as a tourist" (Rosa). Thus proving one's worth whilst on location was a self-doubt and a source of anxiety. For others whose skills were always in demand, it was about living up to the expectations that their role demanded: "all of my concerns revolved around being able to earn my keep from a science perspective" (Ruth).

\subsection{Happiness, Contentment and Volunteering}

When participants were asked what aspects of the trip had instilled them with a feeling of happiness, most of the answers concerned the wildlife or trip experiences rather than the volunteering or the conservation aspects. Experiences that instilled the greatest feelings of happiness included the following:

"I enjoy being with people that are on similar wavelengths.... Every day is just happiness" (Richard). "If you see something, you know, whether it's an elephant or a monkey or whatever, it's just something completely different and I love that, just being able to forget everything that's around you and watch something" (Rosa). "Swimming with the elephants... everything else disappeared...in their world and me with them" (Richard). "I just suddenly realize I'm here, I'm doing it, I'm living a dream, it's just a bit overwhelming". (Gavin). "The happiness for me came from the fact that at times you think, oh I'm sitting here on an elephant in the pool on safari, it's like how am I here, how have I got myself here" (James). Finally: "I was lucky enough to be with the group, which saw the herd of elephants coming across just as the sun was going down in perfect silence and seeing them no more than 25 meters in front of me" (Roger). These responses reflect the positive feelings and engagement in the theory of authentic happiness [28] more than the social virtue of doing good for others inherent in eudemonia.

However, there was no doubt that those directly involved with the medical team reflected on their effort with some inner satisfaction suggesting a more eudemonic outcome: "mostly the dental work, you know being able to give something to the villagers and see their happiness at having gotten some help, you know, and not just being a tourist trudging through their country and throwing a few dollars at them but actually helping them physically was very gratifying" (Diana). Conversely feelings of dissonance or 
unhappiness were mostly rooted in three things: First, the short term nature of the medical effort: "I don't feel any, sort of, you know sense of warmth for helping them. I didn't go out there to think I was going to change these people's lives by pulling out some teeth. I don't think what we did is sustainable unless the clinics are run more frequently" (Anita) and "you'll never cover the population need" (Richard). Second, came feelings of power distance: "I didn't really like the trip to the village, it felt too colonial" (Gavin) and finally, the sense of being 'a spare part' or inadequate if not directly involved in what was perceived as being the most useful. The most unanimous reason for inner happiness came from the sense of feeling lucky and privileged. Almost everyone had overwhelming feelings of how lucky they were to be able to take part. Equally lucky to "grow up in the West in a reasonably privileged background having had free education, having had decent health care, however much we complain about it sometimes. You look at the way people are living here and you think, you know, some people just don't know they are born back at home" (Rosa). "I just feel so privileged and I think that whole overwhelming feeling that I've got so lucky, makes me feel so grateful and that makes me happy" (Gavin).

\section{Conclusion}

Volunteer, or purposeful, travel is bound by paradoxes; it is not just about personal escape but also an inner quest to better understand the world and the people in it. Above all, this expedition experience heightened the inner search for self within a blurred boundary between work and leisure. It enhanced their self-respect and self-belief. Existing outside their personal comfort zones allowed them to understand themselves better and to fulfil their potential as contributing individuals. It was a route to becoming more virtuous but only if they felt themselves to be useful. The findings of this study also indicate that although this search for meaning and purpose is important for the participants, the virtue of doing good for others came second to fulfilling personal goals and ambitions. The happiest moments were rooted in personal enjoyment, in feeling lucky and living the dream which tend more towards hedonism than eudemonism. Whether purposeful travel contributes to eudemonic outcomes very much depends on whether individuals feel useful and engaged in the overall project. If they are not then the boundary between purposeful travel and vacation is blurred and the feeling of being part of something important and virtuous is tenuous.

\section{References}

1. M. Callan, S. Thomas, In M. Novelli (Ed.) Niche Tourism 183-200 (2005)

2. C. Noy, Annals of Tourism Research, 31, 78-102, (2004)

3. R. Scheyvens, Tourism for development. Pearson Education Ltd , 202, (2002)

4. M. Rogers, Travel Agent 331, 3, 20-24, 20 (2007)

5. C. Dykhuis, The Can. Undergrad J. of Development Studies, 7, 3, (2010)

6. A. W. Bailey, K. I. Fernando, J. of Experiential Education, 33, 4, 406-410 (2011)

7. C. Noy, Annals of Tourism Research, 31, 78-102 (2004)

8. Alexander, Z. J. Of Hosp. Marketing and Management, 21, 7, 779-799 (2010)

9. N.J Gray, L.M. Campbell, J Sustain Tourism, 15, 5, 463-482 (2007)

10. N. Uriely, A. Reichel, Tourism Recreation Research, 28, 3, 57-62 (2003)

11. S. Wearing, Volunteer Tourism, CABI, Wallingford, (2001)

12. H. L. Sin, Annals of Tourism Research, 36, 3, 480-501(2009)

13. A. Matthews, In K.D. Lyons \& S. Wearing (Eds.), Journeys of discovery (2008)

14. E.M. Raymond, C.M. Hall, J Sustain Tourism, 16, 5, 530-543 (2008)

15. H. L. Sin, Annals of Tourism Research, 36, 3, 480-501(2009)

16. A. Coghlan, D. Fennell Annals of Leisure Research, 12, 3-4, 377-402 (2009)

17. S. Filep, M, Deery, Tourism Analysis, 15, 4, 399-410 (2010)

18. L. Chen, J. S. Chen, Tourism Management, 32, 2, 435-442 (2011) 
19. S. Brown, Current Issues in Tourism, 8, 6, 479-496 (2005)

20. S. Gabrowski, S. Wearing, CAUTHE Proceedings, S. Australia, 8-11 February (2010)

21. E. G. Clary, M. Snyder, M. Ridge, R. D. Copeland, A. A, Stukas, J. Haugen and P. Meine, J.of Personality and Soc.Psych. 74, 1516-1530 (1998)

22. M. E. Seligman, Authentic Happiness (2002)

23. L. W. Henderson, T. Knight, Int. J. of Wellbeing, 2, 3, 196-221 (2012)

24. B. Grindle, The Biology of Happiness (2012)

25. C. L. M. Keyes, J. Annas, J. of Positive Psychology, 4, 3, 197-201 (2009)

26. S. Filep, J. Hosp. Tour. Res. 38, 266-274 (2012)

27. H. J. Rubins and Rubins, I. S. Qualitative Interviewing (1995)

28. M. E. Seligman, Flourish - An New Understanding of Happiness (2011) 